\title{
生活体験を基軸とする親子キャンプの効果： 子どもを見まもり育てるコミュニティづくりを目指して
}

\section{菊田 文夫 ${ }^{1}$ 米田 朝香 $^{2}$}

\section{Living experience of camping in parents and children : creating a community where all adults protect and raise all children}

\author{
Fumio Kikuta ${ }^{1}$ and Asaka Yoneda ${ }^{2}$
}

\begin{abstract}
This study aimed to explore whether the living experience of parent-child camping would be able to create a basis where all adults would watch over and raise all children, and what contribution the camping experience would make in relation to child-raising support. Questionnaire responses from parents who participated in a camp suggest that sharing the living experience through camping and living in large-sized family groups may be expected to create support systems for helping children beyond one's own immediate family environment. Questionnaire responses on realizations or opinions of discoveries made through participation were arranged into the following categories : "I learned about group lifestyles by interacting with others," "Others cared for me or were nice to me," and "Camp became a place where I could feel safe." Parent-child camping experiences can play a large role in creating a great opportunity to facilitate intergenerational interactions outside one's own family, as well as developing strategies to create a community where all adults watch over and communally raise all children. Furthermore, how participants wanted their family to live during the parent-child camping experience was arranged into the following categories : "I want to create opportunities for collaborating with others outside the family in daily life," "I want to create opportunities for interacting with others of different ages, outside of the family", "I want to be involved in the development of the children of other families." Compared to before camping, the "emotional scolding" item in the nurturing skill scale on the questionnaire was significantly decreased after camping. Changes in parents' behaviors that may occur as a result of the camping experience may contribute to a reduction in aggressive behaviors in children.
\end{abstract}

Key words : parent-child camping, living experience, child-raising support, community creation 親子キャンプ，生活体験，子育て支援，コミュニティづくり

\section{I 緒 言}

近年, 特に都市部においては核家族化が進み, 子育てに不安を感じる母親が多くみられるように
なってきた. NPO 法人子育て学協会 (2014) が 行った 6 歳以下の未就学児童を子に持つ母親を対 象とする調査によると，「いろいろ心配事がある」 への回答が $58.6 \%$ ，「子育てに自信が持てない」

\footnotetext{
1 聖路加国際大学看護学研究科基盤領域（健康教育）

2 東海大学文学部

${ }^{1}$ St. Luke's International University Social Sciences \& Humanities/Fundamental of Research (Health Education)

${ }^{2}$ Tokai University School of Letters
} 
表 1 親子キャンプへの参加家族数, ならびに参加者の年齢構成

\begin{tabular}{|c|c|c|c|c|c|c|}
\hline \multirow[b]{2}{*}{ 実施年 } & \multirow{2}{*}{$\begin{array}{c}\text { 参加家族数 } \\
\text { (家族） }\end{array}$} & \multirow{2}{*}{$\begin{array}{l}\text { 大人 } \\
\text { (名) }\end{array}$} & \multicolumn{3}{|c|}{ 子ども（名） } & \multirow{2}{*}{$\begin{array}{c}\text { 子どもの合計 } \\
\text { (名) }\end{array}$} \\
\hline & & & $\begin{array}{l}\sim 5 \text { 歳 } \\
\text { (幼児) }\end{array}$ & $\begin{array}{c}6 \text { 歳 } 8 \text { 歳 } \\
\text { (小学校低学年) }\end{array}$ & $\begin{array}{c}9 \text { 歳 11 歳 } \\
\text { (小学校高学年) }\end{array}$ & \\
\hline 2009 & 5 & 8 & 2 & 2 & 4 & 8 \\
\hline 2010 & 7 & 11 & 5 & 3 & 4 & 12 \\
\hline 2011 & 8 & 9 & 2 & 6 & 2 & 10 \\
\hline 2012 & 15 & 17 & 2 & 10 & 5 & 17 \\
\hline 2013 & 10 & 16 & 8 & 7 & 1 & 16 \\
\hline 2014 & 15 & 18 & 6 & 9 & 5 & 20 \\
\hline 2015 & 13 & 16 & 4 & 10 & 1 & 15 \\
\hline 計 & 73 & 95 & 29 & 47 & 22 & 98 \\
\hline
\end{tabular}

への回答が $48.4 \%$ みれる. 現代はインター ネットなどを通じて, 自らが必要とする情報を容 易に手に入れることができる便利な環境にあるに もかかわらず，育児不安が多くの母親にみられる という現状がある.

上野ほか（2010）が述べているように，受験戦 争が激しくなった 1980 年代には, 自分の子ども が落ちこぼれることなく，立派に成長できるよう な子育てをしなくてはならないという母親の役割 意識が高まり，育児に自信が持てなくなる母親が 増加した。これに核家族化や近所づきあいの希薄 化などで, 育児について相談する相手を身近に求 めることができず，その結果として，育児の知識 を育児書に求める, 育児のマニュアル化傾向を指 摘している. 三菱 UFJリサーチ＆コンサルティ ング（2014）の調査によると, 子育てについて相 談する相手として，70\%以上の母親が，第 1 位に 「配偶者やパートナー」, 第 2 位に「自分の母」を あげている. 2002 年に行われた同様の調査で第 3 位にあげられていた「近所の知人」は，2014 年の 調査によると第 8 位に後退しており, その割合も $47.1 \%$ から $20.0 \%$ へと減少している.さらに, 「子育ての悩みを相談できる人がいる」と回答し ている母親が 2002 年には $73.8 \%$ みられたのに対 して, 2014 年には $43.8 \%$ と激減している。これ らの結果から, 現在, 子育て中の母親は, その不 安や悩みを解決するために, 居住する地域の資源 を活用せず，家族内で解決しょうと努めているこ とが示唆される. その一方で, 日本労働組合総連 合会（2013）の調査によると, 20 歳以上の男女 3000 名のうち,「子育ては社会全体でするものだ
と思う」に肯定的な回答を与えたものの割合は, 20 歳代で $28.2 \%, 30$ 歳代で $27.9 \%$ とみられお り，若い世代が自らの子育てについて，社会の支 援を少なからず期待していることがわかる.

このような現代の子育て事情を鑑み, $\mathrm{S}$ 大学健 康教育学研究室では, 大人皆で子どもを見まもり 育てるコミュニティづくりを目的として, 子ども とその保護者が生活体験をともにする夏期親子 キャンプを 2009 年から継続して実施している.

本研究では, これらのキャンプが都会で生活す る家族の交流を促すことによって，大人皆で子ど もを見まもり育てる雲囲気の醉成を始めとする, このキャンプの目的を達成することができたの か, さらに，子育て支援に関してどのような貢献 を果たすことができたのか，について明らかにす ることを目的とする。

\section{II方 法}

\section{1. 研究対象}

本研究では, 2009 年から 2015 年の毎年 8 月に 静岡県伊東市の公立施設において, 幼稚園児, あ るいは小学生の子どもを持つ家族を対象に 2 泊 3 日で実施した 7 回の親子キャンプの効果について 検証した．本研究の対象は,これらのキャンプに 参加した 65 家族の母親である。なお，これらの キャンプヘの参加家族数, ならびに参加者の年齢 構成は表 1 に示す通りである.

\section{2. 募集の方法と指導体制}

親子キャンプの参加者募集については, キャン 
プの約 1 カ月前までに, 東京都中央区立の小学校 に募集パンフレットの全校配布を依頼することに よって行った.

また,これらのキャンプの指導にあたっては, 大学教員 1 名と看護師複数名に加えて, 看護学部 の学生複数名を含む, 10 名程度がスタッフとして 関わる体制をとった。ささらに，海遊びのアクティ ビティに関する安全確保のため, ライフセーバー の有資格者 1 名が毎回, 必ずスタッフとして参加 することとした.

\section{3. 親子キャンプの目的と活動内容}

本研究の対象とした親子キャンプでは, 自然豊 かな環境を活用しながら, 魅力的な自然体験や冒 険体験，世代間交流を含む生活が体験できるプロ グラムづくりを目指してきた。これらの特徴は次 の 6 点である.

1）自然とふれあうアクティビティを通して，い のちを感じる.

2 )「このひととき」を大切に想い,ていねいに時 を過ごす生活を体験する。

3 ) すべてのアクティビティに，親子（家族）が 全員で参加する.

4 ）大人皆で子どもを見まもる，まるで大家族の ような生活を営む.

5 ）親の気づきを，今後の日常生活にどのように 活かしていくか,について考える機会を得る.

6 ）居心地の良い常にオープンな雲囲気をつく る。

なお，このキャンプの目的は, 次の 7 点である.

(1)さまざまな体験を通して, 子どもの成長を実感

し，子どもの新たな面を発見する機会を得る.

(2)喜びや感動体験を共有する.

(3)自らの子育てについての気づきを得る.

(4)互いに感謝の気もちを伝え合う.

(5)他の家族と集団生活を送るなかで子どもたちを 見まもり育てる雲囲気づくり.

(6)自然体験活動を通して,「自然」や「いのち」の 大切さを感じる.

(7)参加者が親子キャンプで体験・発見したことを, 自らの日常生活に活かそうとする動機づけを促 す.

さらに, 本研究の対象とした 7 回の親子キャン
プに共通するアクティビテイが, 上記(1)から(7)に あげた目的の何れに関係するものかについては, 表 2 に示す.

それぞれのアクティビティと，これら 7 つ目 的との関係は次の通りである。

\section{・アイスブレイキング}

このキャンプで初めて出会う, さまざまな年代 の家族以外の参加者全員と最初に交流する場とな る. そのため, 自分の子どもと家族以外の参加者 との関わりについて親が最初に観察できる場とな るため, 目的(1)に関係するアクティビティとして 捉えることができる.さらに，これらのキャンプ に参加した大人皆で子どもたちを見まもる雲囲気 づくりの契機として，目的(5に関係するアクティ ビティである。具体的には,「ネームトス」,「ライ ンナップ」,「木こりとリス」など, 野外活動にお いて互いを知り合うためのアイスブレイキングで しばしば活用されるゲームを行った。

・アウトドアクッキング

大人も子どもも，自分にできる役割について責 任を持って担い, 他者と協働して料理をつくりあ げる過程と, 参加者皆で楽しく食卓を囲む食事の 時間を親子で体験できる, 目的(1), 目的(2), 目的 (4)，目的5に関係するアクティビティである。さ らに，協働作業の過程において生まれる親同士の 交流は目的(3に, また, 子どもに対する大人の声 かけや，子どもが自発的にお手伝いする姿を観察 し，自らの子育てへの気づきを得る場として目的 (7)に関係するアクティビティである. 参加者が火 おこしや調理作業を協働し，「ブイヤベース」,「パ エリア」,「クラムチャウダー」などの鍋料理を主 とするメニューに挑戦し, 参加者およびスタッフ 全員で食卓を囲んだ.

・絵本の読み聞かせ

生きることやいのちの尊厳について描かれた絵 本を，子どもたちに読み聞かせる．就寝前のひと ときに, 参加者全員で時間と場所を共有するため, 大家族のような雲囲気づくりを意図した目的(5) 関係するアクティビティである.スーザン・バー レイ「わすれられないおくりもの」, ハンス・ウ イルヘルム「ずーっとずっとだいすきだよ」な どの絵本を読み聞かせた. 
表 2 親子キャンプのプログラム

\begin{tabular}{|c|c|c|c|}
\hline & 第 1 日 & 第 2 日 & 第3 日 \\
\hline 午 前 & & $\begin{array}{l}\text { ラジオ体操 } \\
\text { 朝食（給食） } \\
\text { 海遊び1)(2)(5) } \\
\quad \text { (伊東市の宇佐美海岸で海水浴と } \\
\text { 磯遊びを楽しむ活動） }\end{array}$ & $\begin{array}{l}\text { ラジオ体操 } \\
\text { 朝食（給食） } \\
\text { つくって遊ぼう(1)6 } 6 \\
\text { （自然の素材を使って, 笛や空気鉄 } \\
\text { 砲, 竹トンボをつくって遊ぶ活動） }\end{array}$ \\
\hline 午 後 & $\begin{array}{l}\text { オープニング } \\
\text { オリエンテーション } \\
\text { アイスブレイキング(1) } \\
\text { (体を動かすゲームを楽しみなが } \\
\text { ら, 家族を超えて子どもと大人 } \\
\text { が親しくなるための活動) } \\
\text { アウトドアクッキング } \\
\text { (1)(2)(4)(5)(7) } \\
\text { (火おこしと食材の調理に子ども } \\
\text { と大人が協力して取り組む活動) } \\
\text { タ食（自炊） }\end{array}$ & $\begin{array}{l}\text { 昼食（給食；流しそうめん） } \\
\text { フリータイム } \\
\text { おやつの時間（スイカ割り） } \\
\text { 夕食（給食） }\end{array}$ & $\begin{array}{l}\text { 昼食（給食） } \\
\text { ふり返りシートへの記入 } \\
\text { ふり返り·分かちあいの会 } \\
\text { (2)(4)(5)7 } \\
\text { (親子キャンプに参加して, それぞ } \\
\text { れの家族が新たに発見したこと, } \\
\text { 感じたことを皆で共有する活動/心 } \\
\text { の引き出しのラブレタ一の配達) } \\
\text { スライドショー } \\
\text { (2)(4)(5) } \\
\text { (親子キャンプで撮影した写真をス } \\
\text { ライドショーとして スタッフか } \\
\text { らのメッセージを伝える活動) } \\
\text { 解散 }\end{array}$ \\
\hline 夕食後 & $\begin{array}{l}\text { 絵本の読み聞かせ(5) } \\
\text { （生きること, いのちの尊厳につ } \\
\text { いて描かれた絵本を紹介する活 } \\
\text { 動） }\end{array}$ & $\begin{array}{l}\text { 心の引き出しのラブレター } \\
\text { (1)(2)(4) } \\
\text { (参加者とスタッフ, それぞれが, } \\
\text { メッセージを贈りたい 相手に } \\
\text { 手紙を書く活動) } \\
\text { ロマンチックキャンドルナイト } \\
\text { (1)(2)(4) } \\
\text { (参加者とスタッフが, ひとりひ } \\
\text { とつずつのキャンドルを手にし } \\
\text { ながら, } 2 \text { 日間の想いを語り, こ } \\
\text { れらを皆で分かちあう活動) }\end{array}$ & \\
\hline
\end{tabular}

それぞれのアクティビティに付記された番号は，親子キャンプの目的(1)から(7)との関連を示すものである.

\section{・海遊び}

自然体験活動を通して新たな体験や感動, さま ざまな年代の参加者との交流が期待できる, 目的 (1), 目的(2), 目的(6)関係するアクティビティで ある。ささらに, 大人皆で海で遊ぶ子どもたちの安 全を見まもる雲囲気が自然に醸成されるため, 目 的(5)にも関係するアクティビティである.

・心の引き出しのラブレター

参加者とスタッフ, それぞれが, 嬉しかったこ
と，楽しかったこと，感謝の気持ちなどを伝えた い相手にメッセージカードを贈る, 目的(2)と目的 (4)に関係するアクティビティである。 また, 子ど もからメッセージを受け取った大人が, 子どもの 成長を感じる契機として，目的（1)と目的（7)に関係 するアクティビティである.

・ロマンチックキャンドルナイト

参加者とスタッフ全員が，ひとりひとつずつ キャンドルを手にしながら, このキャンプで感じ 
た想いについて参加者全員が語り，これらを皆で 分かちあう，目的(1)，目的(2)，目的(4)，目的(7)に 関係するアクティビティである.

・つくって遊ぼう

自然の素材を使ったおもちゃづくりと昔の遊び を, 親子で共に体験する活動は, 目的(1), 目的(2), 目的6に関係するアクティビティである. 元公立 中学校長の指導のもと, 空気鉄砲, 竹とんほ，紙 の吹き矢を親子が協働して制作し，それらを用い た遊びを体験するアクティビティである.

・ふり返り・分かちあいの会

親子キャンプに参加して感じた想いや新たに発 見したことなどについて, 家族ごとに話し合い, これらを参加者全員で分かちあう活動は, 目的(2), 目的(4), 目的(5), 目的(7)に関係するアクティビティ である。

・スライドショー

スタッフから参加者に向けて, 親子キャンプの ふり返り, 感謝の気もちを伝えるスライドショー は, 目的(2), 目的(4), 目的(5), 目的(7)に関係する アクティビティである.

なお，アウトドアクッキングを行う 1 日目の夕 食以外の食事については, 宿泊した施設に給食を 依頼した．また，フリータイムは，参加者が自由 に過ごす時間として位置づけ，スタッフは積極的 に関わらなかった。

\section{4. 調査内容}

本研究においては, 次の 2 点に関する無記名の 質問紙調查を行った。

（1） 2009 年から 2015 年の親子キャンプについ ては, 何れも最終日に, 質問 1 「親子キャンプに参 加して, どのような発見や気づきがあったか」, 質 問 2 「親子キャンプで家族以外の人びととふれ合 う機会を得て, 感じたこと気づいたこと」, 質問 3 「親子キャンプで体験したことを, 今後, 家族の日 常生活（生きかた）にどのように活かしていきた いと考えているのか」, に対する回答を自由記述 形式で求めた.

（2）２015 年の親子キャンプでは，キャンプ前後 で母親の養育スキルに変化が見られるか否かを確 認するため, 第 1 日目のオープニング（キャンプ 開始前）と，第 3 日目のクロージング（キャンプ
終了時）に, 三鈷（2008）が開発した養育スキル 尺度を用いた測定を行った。この尺度は,「誘導 的しつけ」,「感情的叱責」,「注目・関与」,「スパ ンキング」,「物的報酬」「援助的コミュニケーショ ン」,「きげんとり」,「不適切行動の無視」,「身体 的攻撃」の下位尺度から構成されており, それぞ れの下位尺度に含まれる質問項目は 4 件法による 回答を求めるものである.

\section{5. 分析方法}

調査内容（1）については，「ふり返りシート」 に自由記述で回答のあった文章を，ひとつひとつ の文に分割したうえで，質問の回答として不適切 なものは分析の対象から除いた. なお, 本研究で は,「文」を, 複数の単語で構成された, ひとつの まとまった内容を表現しているもので,「.」(句点) で終わっているもの, また「文章」を, 複数の文 から構成された，何らかの意見を表現しているも のと定義して文章を文に分割した。その後，質問 1 と質問 2 の回答を, これらのキャンプに参加し て得た発見や気づきという視点から，また，質問 3 の回答を, 家族の今後の日常生活 (生きかた) に 活かしていきたいことがらという視点から，それ ぞれ KJ 法を用いて分類した。 これらの結果に基 づいて，親子キャンプの目的が達成されているか どうかについて評価した。

また, 調査内容（2）については, 養育スキル尺 度を構成している9つの下位尺度それぞれの得点 について，キャンプ前後で有意な差が認められる か否かを確認するため, Wilcoxonの符号付き順 位和検定を行った。なお, 統計解析には, IBM SPSS Statistics 23 を用いた.

\section{6. 倫理的配慮}

親子キャンプへの参加申込書において本研究に 関する説明を行い, これに対する同意を得た。ま た，母親を対象とした質問紙調査の実施にあたっ ては, 個人や家族が特定できないように, 質問紙 の内容および回収方法について配慮した.

\section{III 結 果}

調査内容（1）については, 2009 年から 2015 年 
の親子キャンプに参加があった 73 家族のうち, 65 家族の母親からの回答を得た。 また, 調査内容 （2）については，2015 年の親子キャンプに参加が あった 10 家族のうち, 9 家族の母親からの回答を 得た。

\section{1. 親子キャンプに参加して得た発見や気づき について}

「ふり返りシート」の質問 1 と質問 2 に対して 自由記述形式で回答された文章を文に分割したと ころ 176 の文を得た。これらについて分類した結 果を表 3 に示す.

これによると, 親子キャンプに参加して得た発 見や気づきについては 13 のカテゴリーに分類す ることができた。「子どもの成長を確認・実感で きた」に分類できた文が 45 と最も多く, 次いで「普 段の生活では見えない子どもの姿を見ることがで きた」が39,「親自身の生活や子育て観をふり返 る機会になった」が 21 ,「他者との関わりを通し て, 集団生活について学ぶことができた」と「自 分の子育てについての課題が発見できた」が 16 あった。一方, 少数ながら,「いのちや生きる営み の大切さを感じた」が 8 ,「自然とふれ合う大切さ を感じた」と「みんなで大家族になれた」がとも に 7, 「子どものさらなる成長への期待や希望を感 じた」と「他者から気にかけてもらったり, 優し さにふれることができた」がともに 5 ,「子どもの 素晴らしい力を感じた」と「子どもが安心できる 居場所になった」に分類できたものがともに 3 , 「親になれた喜びを感じた」が 1 あった。

\section{2. 家族の今後の日常生活（生きかた）に活か していきたいことがら}

「ふり返りシート」の質問 3 に対して自由記述 形式で回答された文章を文に分割したところ 84 の文を得た。これらについて分類した結果を表 4 に示す.これによると, 家族の今後の日常生活に 活かしていきたいことがらについては 13 のカテ ゴリーに分類することができた。「子どもを少し 離れた距離から見まもりたい」に分類できた文が 16 と最も多く, 次いで「異なる年齢の家族以外の 他者と接する機会をつくりたい」が $10, 「 今$ 後の 生活でも家族以外の他者と協働できる機会をつく
りたい」,「今後の子どもの成長に期待したい」,「子 どもにできる役割を任せたい」に分類できた文が, それぞれ 9 あった。 さらに，「子どもが自立した 人間に成長できるように支援したい」が 8 ,「自然 とふれ合う機会をつくりたい」が 7, と「子どもと 関わる時間や機会を増やしたい」が 6 ,「子どもに ポジティブフィードバックを心がけたい」が 5 , 「ゆっくりとした時間を過ごしていきたい」が 4 , 「親子キャンプで得たつながりを糧に，子育てを がんばっていきたい」,「これからも子どもにたく さんの体験をさせたい」,「他の家族の子どもの成 長にも関わっていきたい」が, それぞれ 3 あった.

\section{3. 親子キャンプ前後の養育スキル尺度得点の 差について}

表 5 に示すとおり, 養育スキル尺度を構成して いる 7 つの下位尺度得点のうち,「感情的叱責」に ついては, キャンプ前に比べてキャンプ後の得点 が有意に低下している $(\mathrm{p}=0.018)$ ことがわかっ た.しかしながら, その他の下位尺度については, キャンプの前後で有意な差は認められなかった。 また，「身体的攻撃」については，この尺度を構成 する質問項目すべてに回答している母親が 9 名中 3 名であったため，分析から除外した。

\section{IV 考察}

\section{1. 親子キャンプに参加して得た発見や気づき について}

表 3 に示すように「子どもの成長を確認・実感 できた」と「普段の生活では見えない子どもの姿 を見ることができた」のカテゴリーに含まれる文 は, 2009 年から 2015 年までのすべての実施年に おいて回答がみられることから，このキャンプの 目的(1)，すなわちこれらのキャンプを体験するこ とによって, 子どもの成長を実感でき, 子どもの 新たな面を発見できたと考えられる。

朴・杉村（2009）は，子育てに関する省察につ いて 3 つの階層と 3 つの領域から構成されるモデ ルを仮定し, 親自身に関する省察, 子どもに関す る省察，他者をとおした省察それぞれを測定する 尺度の構成を試みている，これによると，3〜 5 歳 児の子どもを育てる親について，子育てにおける 


\section{表 3 親子キャンプに参加して得た発見や気づき}

分類したカテゴリーそれぞれに含まれる文の例と文の数
子どもの成長を確認·実感できた

·興味あることに集中している娘を見て驚いた。

普段の生活では気づかない（or 見せない）子どもの姿だった，あまりに楽しそうなので，東京に戻ってマンション暮らしに戻れる か心配になるくらいだ.

家庭ではあまり見せない一面を見ることができた.（リーダーシップ, 他人とのコミュニケーション，下級生の面倒をみるなど）

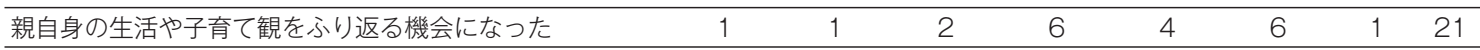

どの家族も大切な子どものために頑張っていると思う. 方法はいろいろだけれど向かうところは一つなんじやないかと思った。 他の家族の人と一緒に生活することは，子どもだけではなく，大人も自分たちの生活を見直す意味で，大変有意義であったと思う。 子どもと自分との関係を，他のお母さんたちから見て，話してもらえたことが良かった.

他者との関わりを通して, 集団生活について学ぶことがで きた

$\begin{array}{lllllll}2 & 2 & 5 & 1 & 4 & 1 & 16\end{array}$

普段はこんなに多い人数で食事をしたり，大部屋でみんなで一緒に寝たり，何をするにも団体行動で，人を待ったり，待たれたり， 人に譲ったり，譲られたり，経験ができなかったことが自然に学べた気がする。

·団体生活の中で, 子ども心にも役割分担の大切さを気づかせてくれたスタッフに感謝.

大家族のような生活に，共に子どもをほめ，しかる，自然な生活ができた.

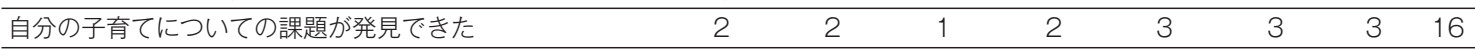

·他の家族の皆さまの様子を見ていても, 子どもに介入する親御さんより，子どもを信頼し任せる親御さんの方に好感が持てるし，お

子さまもしつかりしているように感じた.

子どもと一緒に体験し，一緒に感じてあげることの大切さに気づいた

これからも, 集団生活をしていく中で, 自分のやるべきことを考えさせたいと思う.

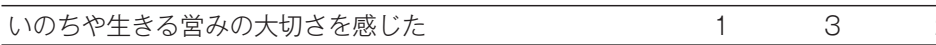

·「いのち」があるとは,「つながり」を感じることだと思う. 多くのつながりが得られて, いのちのチャンネルが増えたと思う.

今ここにいる, すぐ目の前の人，隣の人のいのちを大切にすることが, 自分にとって何よりのこと, と感じた.

お年を召した方から０歳児まで (の参加者を見て)，(のちが引き継がれていることを実感した.

\begin{tabular}{llllllll}
\hline 自然とふれ合う大切さを感じた & 1 & 6 & 0 & 0 & 0 & 0 & 0 \\
\hline
\end{tabular}

·本物に, 自然に触れさせることの大切さ

・たくさんの生物がいて, 自分がいて, このような場所にいることが自然であり, 都会にいることが不自然ということに気づかされた. ·子どもが簡単に接することのできるいのちにあふれ, 子どもの成長にプラスになる環境だった。

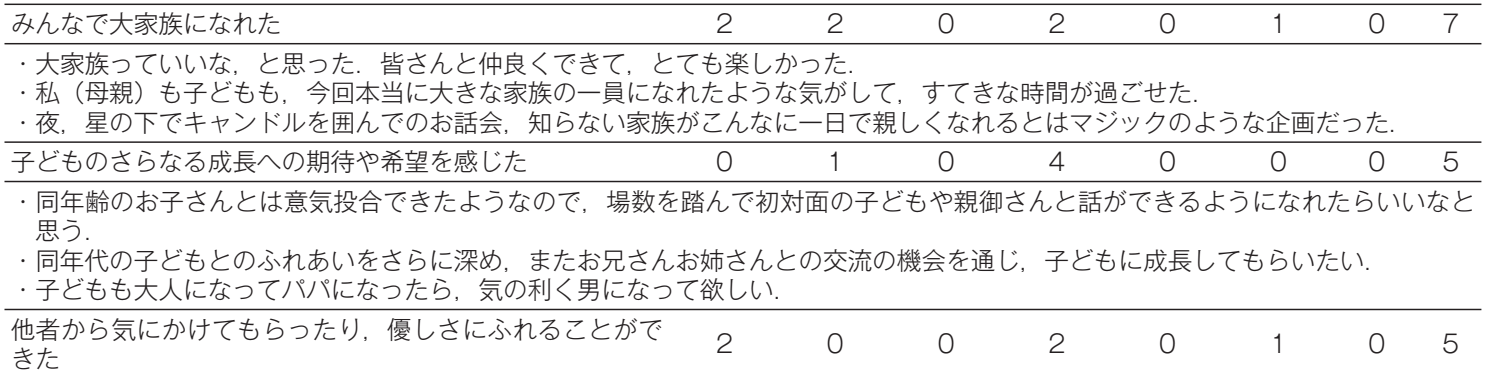
きた

·皆の笑顔で幸せになつた.

子どもは最年少だし,ついていけないことも多々あった。 そのなかでみんなが温かい目で見まもってくださり,一緒に遊んでくれて, 本当に良かったと思う.

皆さんの優しさにつながっている子どもの表情は大変輝いていた.

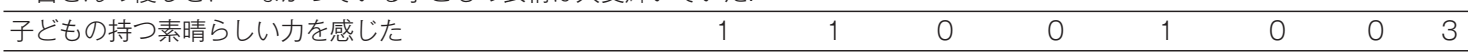

子どもはホントにすぐにだれとでも仲良くなってしまうからスゴイ!

子孞もは子ども同士ですぐに仲良くなれる. 子どもの力はすばらしいと思った

全く見たことのない，知らない人と共同生活することを嫌がらずにできたことがスゴイ！と思った

\begin{tabular}{|c|c|c|c|c|c|}
\hline が安心できる居場所になつた & 0 & 1 & 0 & 0 & 1 \\
\hline
\end{tabular}

子どもも私（母親）の顔色をうかがうこともなくなり, のびのびとして過でしていた

このキャンプが安心でき, 楽しいところだと感じた証拠だと思う.

子どもは, 見守られた安全な環境にいるから,のびのびと幸せに成長していける（ことに気づいた）

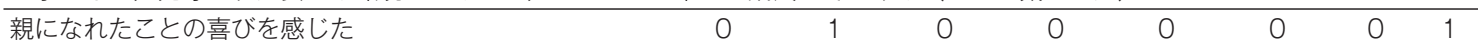

·娘が産まれてきてくれて，お母さんになることができて，親子になって，親子キャンプにも参加することができて，とても嬉しかっ た. 
表 4 家族の今後の日常生活（生きかた）に活かしていきたいことがら 分類したカテゴリーそれぞれに含まれる文の例と文の数 2009年 2010 年 2011 年 2012 年 2013 年 2014 年 2015 合計

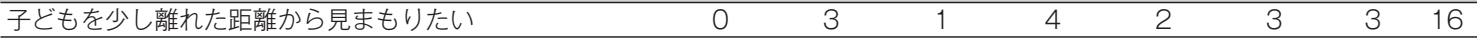

·キャンプで他のお子さんたちに接したように, 少し間をおいて, 見守れるようになりたい.

·私 (母親) も言うことばかりではなく，子どもの考える時間を待てるように心がけていきたい.

·子どもがチャレンジする姿を，たとえ失敗しそうなときでも，手を貸さずに見守ってみようと思う.

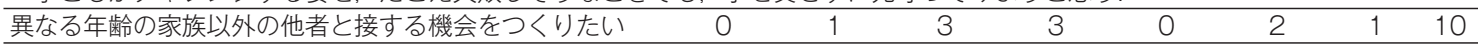
·同年齢のお子さんとは意気投合できたようなので, 場数を踏んで初対面の子どもや親御さんと話ができるようになれたらいいなと 思う.

異なる年齢の子どもたちが参加するようなプログラム等にもまた参加させてみたいと思った

大人も子どもも混ざっての団体生活というのは, 子どもにとっても意味がある. 子どもは皆で育てるということが, 子どもの多様性 を育むのだと思う.

今後の生活でも家族以外の他者と協働できる機会をつくり たい

·知らない方との協力する姿勢を今後も育てていければと思う.

·優しい気持ちでお互いに協力し合い, 幸せに生きていける社会づくりに貢献したいと思う.

・いつもの知っている人だけでなく、いろいろな人と出会って話をしたり,一緒に遊んだりすることも楽しいのだということを忘れず に, これからもたくさんの人と出会えるように努力していきたい.

\begin{tabular}{llllllll}
\hline 今後の子どもの成長に期待したい & 0 & 2 & 0 & 4 & 0 & 3 & 0 \\
\hline
\end{tabular} ·子どもが少しずつ成長するように, 今回のようなプログラムの機会があれば, どんどん参加して, 団体行動や思いやりを持てる子ど もになってくれることを期待している.

·今まではお世話してもらう側が多かったが, これからは，お姉さんの意識をもって，お世話する側になっていって欲しい，

·自分以外の人のことをもつと思いやれる, もつと考えられるようになつてほしいなあと, 日々の生活でも少しずつ親子で話していき たい.

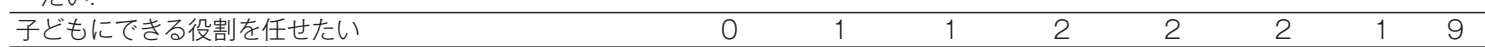

·子どもに関しては, 少しずつお手伝いをやらせていこうと思う

. みんなと仲良く助け合うこと, その助け合いに子どもでもできることは少しでもやり, 力になれるように, 日々の生活でも教えてい きたいと思う.

·お手伝いをしてもらう時, ひと通りのやり方を教えたら, 任せてやってもらおうと思った.

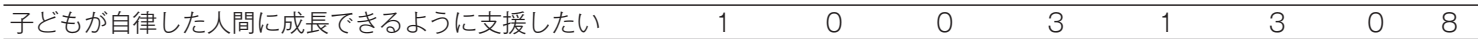

·自分の発言, 行動に責任をもって生活をさせていく.

·子どものコミュニテイに信頼して入れる.（囲い込まない)

·人が困っていたり，色々な場面で, 親に言われなくても子ども自身が考えて, 行動できるようにしていきたい,

自然とふれ合う機会をつくりたい

·まずは, 自然とつながること, を家族で実践していく

・これからも時間をつくつて自然を楽しむ機会を年間を通じて作っていきたい.

·都会の生活では忘れがちな, 自然の恵みに感謝する心をときどき思い出したいと思う.

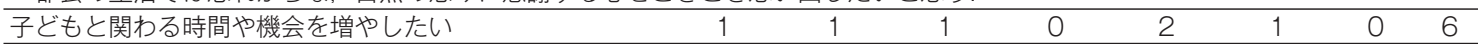

·いつも忙しいという理由で, 子どもと接する時間が取れなかったりすることがあるので, もつと接する時間をたくさんつくつていき たい.

·初めての体験が今後一緒にどのくらいできるだろう？ たくさん同じ時間を過でしたいと思った

·親子で, または友だち同士で一緒になって何かを作るチャンスをもつと増やしてあげられればいいなと思う。

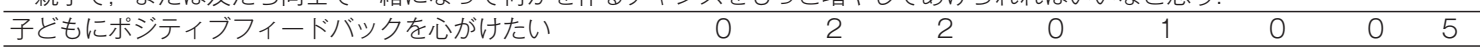

·親というものはその欠点を減点するのではなく, 大切な課題として良い方に導くのが仕事.

·子どもの良いと己ろ悪いところがよくわかったので, これからは厳しくも温かい教育を心がけたい.

·子どもの長所, できることに目線を向けてほめるようにしょうと思った。

ゆっくりとした時間を過ごしていきたい 00

·家に帰っても少し気持ちをゆっくりして, 子どもたちと遊びたいと思う.

・ゆっくり過ごすことの大切さをつくづく感じた。

・のんびりすることの大切さ, 協力することの大事さがわかった.

親子キャンプで得たつながりを糧に, 子育てをがんばって

いきたい

·なかなか日常においては, 親の世界は狭いもので, このキャンプの 3 日間で得られるようなつながりは多く得られない. 今回のキャ ンプを通して得られたことを日常でも少しでも広げていきたいと思う.

・いつもの知っている人だけでなく、いろいろな人と出会って話をしたり, 一緒に遊んだりすることも楽しいのだということを忘れず に, これからもたくさんの人と出会えるように努力していきたい.

・もし，新しいところで人付き合いでつまずくことがあつたら，このキャンプのスタッフの方々のことを思い出し，「ステキな人間は いるんだ!」と信じて, がんばっていこうと思う!

これからも子どもにたくさんの体験をさせたい

·親子そろって, 多くのことを経験させてあげたいと思う

·家族でも, 楽しい体験をできるだけさせてあげたいなあと思った。

·子どもたちにはできるだけ多く，このような色々な経験をさせてあげたいと思う.

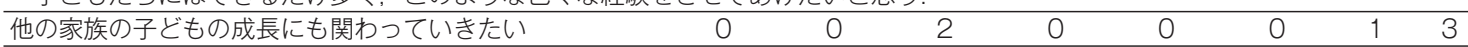

·他の保護者の方々が, わが子ではない子どもたちの面倒も見られてるのを見て, 今回, 私 (母親) はわが子のことだけで手いっぱい だったが, もう少し手がからなくなってきたら, 同様にわが子以外の子にも接することができたらな, と思った。

. 他の家族の子どもも育てるという意識を強く持っていきたいと思う. 


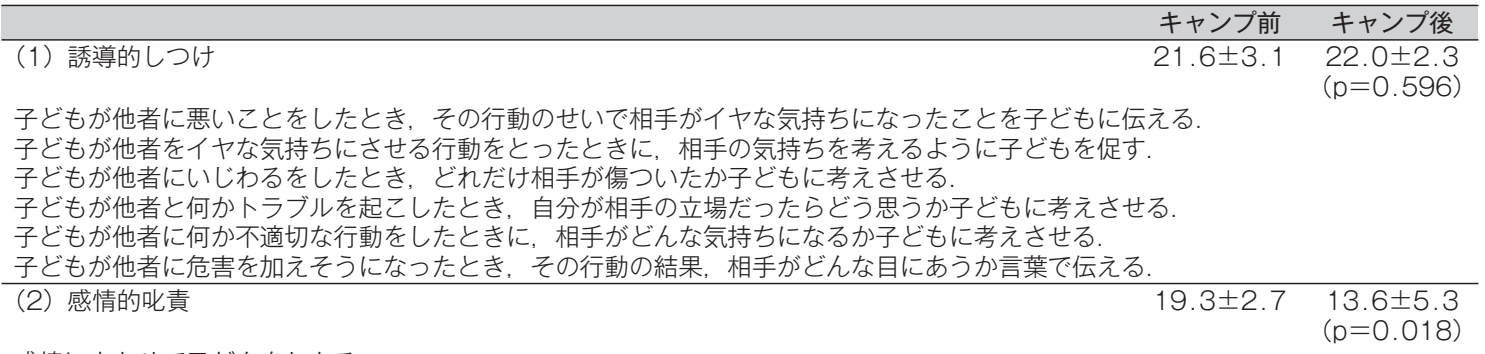

感情にまかせて子どもをしかる.

子どもが悪いことをしたとき, 自分の気分によって叱る程度が変わる.

子どもが悪いことをすると，感情的に怒って言葉で責める.

子どもが何か失敗すると, きつくせめる.

子どもが言うことをきかないと, 大声でどなりつける.

子どもを罰するときには, おどしをつかう.

「良い子にしていなさい」のように, あいまいな指示をついしてしまう.

自分のきげんが悪いと, 子どもが良いことをしてもほめない.
(3) 注目 $\cdot$ 関与
どんなに忙しくても，子どもと話したり一緒に遊んだりする
忙しくても，子どもの行動をしつかり見るようにしている。
どんなに疲れていても，子どもと一緒に運動したりゲームをしたりする
何か家事をしていても，子どもの様子や状況をできるだけ把握するようにしている.
子どもが何をしているかよく見るようにしている.
子どものやっていることを注意深く見守っている.

$18.6 \pm 2.7 \quad 19.3 \pm 3.4$

$(p=0.230)$

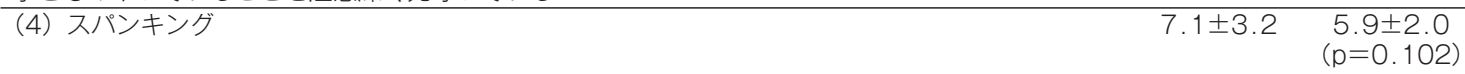

子どもが言うことをきかないと, 子どもの手や足をぴしやりとたたく

子どもが悪いことをすると，子どもの手や足をぴしやりとたたく.

子どもがどうしてもいうことをきかない時には，つい子どもの顔や頭をたたく

子どもが触つてはいけない物を触ろうとした時, 子どもの手や足をびしやりとたたく
（5）物的報酬
$10.8 \pm 1.7 \quad 9.1 \pm 2.3$
$(p=0.196)$

子どもが良いことをしたら、ごほうびをあげる.

子どもが嫌なことでもがんばつていたら，ごほうびを与える.

子どもが苦手なことに挑戦していたら, がんばつたごほうびを与える。

子どもが良いことをしたら, 好きなものを買ってあげる.

(6) 援助的コミュニケーション

何が良かったのか子どもに伝えながらほめる.

子どもが困っているときには, 良い解決策を一緒に探す。

子どもが困っているとき, 言葉で励ます。

子どもの行動を禁止する際には，その行動が他者に与える迷惑を子どもに分かる言葉で伝える.

どんなに時間がなくても，子どもが良いことをしたらほめる。

子どもが悪いことをしたとき, 理由を聞くようにしている。

するべきことを, わかりやすく子どもに伝える

$\begin{array}{lc}\text { (7) きげんとり } & 8.0 \pm 1.9 \\ & (p=0.9 \pm 1.5 \\ & \end{array}$

買い物をしているときに子どもが泣きさけぶと, つい好きなものを買ってあげる

子どもの悪い行動に対して罰を与えると決めても, 子どもが嫌がるとやめる.

子どもがかんしやくをおこすと，すぐにきげんをとろうとする.

子どもに何かさせようとしても，子どもが嫌がると途中であきらめる。
(8) 不適切行動の無視
$7.2 \pm 1.3 \quad 7.1 \pm 1.9$

子どもが泣きさけんで自分の要求を通そうとしても，相手にしない.

子どもがわがままを通そうとしてぐずっても取り合わない.

子どもが注意を引こうとしてめそめそ泣いても取り合わない

(9) 身体的攻撃

感情的になると, つい子どもを押したり, 突き飛ばしたりする.

怒つた時に, つい子どもに物をなげつける.

怒りにまかせて, つい子どもをぶつたり, 蹴つたりする. 
関連要因と省察尺度との相関をみた結果, 「一般 的に自分の子育てをふり返り考え直すなど省察を 行う親の子育てはうまくいっているという認識を 部分的に確認することができた」と述べている. 本研究において，「親自身の生活や子育て観をふ り返る機会になった」のカテゴリーに含まれる文 がすべての実施年においてみられることから，親 子キャンプが親の子育てに関する省察の機会とし て期待できると考えられる.

「自分の子育てについての課題が発見できた」 のカテゴリーに含まれる文は, すべての実施年に おいて回答がみられており, これらの中には, 子 どもに介入する親に比べて子どもを信頼し任せる 親に好感が持てるとともに, 子どもがしっかりし ているように感じられたという記述が複数みられ た。 大学生の親子関係, 自尊感情, 生き方志向が 子ども時代の両親の養育態度とどのような関連が みられるのか, について検討した山下ほか (2010) の研究によると,「母親に保護されすぎていたよ りも, ある程度自律を承認してもらっていた方が, 自己に対して主体的に成長する姿勢を持つことが できる」ことが明らかにされている，子どもを信 頼し, 子どもの主体性を尊重する子育てに価值を 見いだす契機として，親子キャンプが果たすべき 役割は大きいと考えられる.

このように，親子キャンプへの参加によって得 られた発見, 気づきとして,「親自身の生活や子育 て観をふり返る機会になった」と「自分の子育て についての課題が発見できた」のカテゴリーに含 まれる文が，すべての実施年においてみられるこ とは, これらのキャンプの目的(3), すなわち, 自 らの子育てについての気づきを得たことがうかが える。

さらに「他者との関わりを通して, 集団生活に ついて学ぶことができた」のカテゴリーに含まれ る文が，すべての実施年においてみられたこと， 「みんなで大家族になれた」のカテゴリーに含ま れる文が，4回の実施年においてみられたことか ら,これらのキャンプの目的(5にあげた，他の家 族と集団生活を送るなかで子どもたちを見まもり 育てる雲囲気が醸成されつつあったことがうかが える.

一方,「いのちや生きる営みの大切さを感じた」
と「自然とふれ合う大切さを感じた」のカテゴリー に含まれる回答については, すべての実施年には みられなかった。これについては, 海遊びの際に, 磯で生きものと触れあう時間をたっぷり確保でき たか否かによるものであると考えられる.

\section{2. 家族の今後の日常生活（生きかた）に活か していきたいことがら}

表 4 に示すように，「子どもを少し離れた距離 から見まもりたい」と「子どもにできる役割を任 せたい」のカテゴリーに含まれる文は, 2009 年を 除く実施年においてみられた。山下ほか（2010） は, 子ども時代の両親の養育態度が, 子どもが大 学生となった現在の親子関係や自尊感情, 生き方 志向にどのような影響を与えているのかについて 考察している。これによると，「高い自尊感情を 育てるためには, 愛情や共感だけではなく, 過保 護にならず自律を促進する養育態度が重要であ る」こと,「過保護が積極的な生き方志向を持つこ とにネガティブな影響を与える可能性」が示唆さ れている. 親子キャンプの生活体験が，子どもに 対する過保護, 過干渉にあった自分をふり返り, 子どもの挑戦を見まもり，自律を支援する子育て に変えていくきっかけになるのではないだろう か.

「今後の生活でも家族以外の他者と協働できる 機会をつくりたい」と「異なる年齢の家族以外の 他者と接する機会をつくりたい」については, そ れぞれのカテゴリーに含まれる文が 7 回のうち 5 回の実施年についてみられた．高齢者と子どもの 交流モデルを設定し，高齢者との会話の多様性が 子どもの共感性を高めることを明らかにした村山 (2009) の研究にも董付けられるように, 家族以外 の他者, あるいは異なる年齢の他者と子どもとの 交流を望む親の想いは，子どもの共感性を育むた めの礎になると考えられる.

子どもたちが承認を得るために，親から受ける 期待とその達成度（承認の程度）について小学校 4 年生から 6 年生を対象とする質問紙調査を行っ た中井（2007）が「家庭ではわが子を肯定した上 で，その良さを認めることで，わが子のプライド に火をつけることが不可欠である」と述べており， 親が今後の日常生活に「子どもにポジティブ 
フィードバックを心がけたい」と考えていること は, 子どもの自尊感情を高める効果が期待できる.

また「子どもと関わる時間や機会を増やした い」, あるいは「ゆっくりとした時間を過ごしてい きたい」という親の意識は，子どもにさまざまな 体験を促すための基盤として欠かせないものであ る.

「親子キャンプで得たつながりを糧に，子育て をがんばっていきたい」,「他の家族の子どもの成 長にも関わっていきたい」というカテゴリーが抽 出されたことは，親子キャンプの目的(5)，すなわ ち，大人みんなで子どもを見まもり育てる雲囲気 が醉成されているものと考えられる。ささらに,「子 どもの発達には，子どもを取り巻く環境が相互に 影響し合っているとするならば，子育ての責任を 家庭だけに押し付けず，社会全体で子どもを育て る土壤が必要であると考えられる」と佐々木 （2010）が述べているように，家族を超えた世代間 交流を促す貴重な機会として，また，大人皆で子 どもたちを見まもり育てるコミュニティづくりの 方策として, 親子キャンプに期待される役割は大 きいと考えられる.

\section{3. 親子キャンプ前後の養育スキル尺度得点の 差について}

本研究では，養育スキル尺度の「感情的叱責」 については, キャンプ前に比べてキャンプ後の得 点が有意に低下していることがわかった。「「子育 て不安感」「子育て負担感」は, 子どもに対して感 情的に叱るなどの行為と関連することが理解され た」という中山ほか (2014) の研究結果から, 親 子キャンプの効果として, 子育て不安感や子育て 負担感の軽減が示唆される。さらに，「子どもの 攻撃的行動を低減するためには「感情的叱責」を 減らすことが有効である」という三鈷（2009）の 研究結果は, 親子キャンプの効果として期待でき る親の行動変容によって, 子どもの攻撃的行動の 低減に寄与できると考えられる.

なお，本研究では，養育スキル尺度の「感情的 叱責」以外の下位尺度については, キャンプ前と キャンプ後の得点に有意な差が認められなかっ た.これは，個々の母親が自分の子どもと向き合 う, 日常の子育ての場面とは異なり, 親子キャン
プでは，キャンプ期間中のすべての時間を家族以 外の子どもや大人と共有する生活を体験したこと も影響していると考えられる。

\section{$\mathrm{V}$ 結 論}

本研究は, 親子キャンプによって, 大人皆で子 どもを見まもり育てる雲囲気を醸成することがで きたのか, さらに，これらが子育て支援に関して どのような貢献を果たすことができたのか，につ いて明らかにすることを目的とした。本研究の結 果は以下の通りである。

2009 年から 2015 年の毎年 8 月に実施した親子 キャンプの参加者から得た，発見や気づきに関す る回答文 158 を整理した結果, 13 のカテゴリーに 分類することができた．生活体験が共有できる親 子キャンプにおいて, 参加者が大家族のように暮 らす生活を体験することによって，子育てに関す る家族を超えた助け合いが醉成されていくものと 期待できる.

さらに，親子キャンプで体験したことを家族の 日常生活（生きかた）にどのように活かしていき たいと思うか，に関する回答文 84 を整理した結 果, 13 のカテゴリーに分類することができた．特 に，家族を超えた世代間交流を促す貴重な機会と して，また，大人皆で子どもたちを見まもり育て るコミュニティづくりの方策として，親子キャン プに期待される役割は大きいと考えられる.

一方, 2015 年の親子キャンプで測定した養育ス キル尺度の「感情的叱責」については, キャンプ 前に比べてキャンプ後の得点が有意に低下してい ることがわかった． 親子キャンプの効果として期 待できる親の行動変容によって, 子どもの攻撃的 行動の低減に寄与できると考えられる.

\section{VI 本研究の限界と今後の課題}

本研究で対象とした親子キャンプは, 7 年にわ たって実施されたものであり，それぞれのキャン プに参加した家族数や年歯構成が異なっている. また，親子キャンプの効果を検証するにあたって 対照群を設定していないこと, キャンプ前後の比 較を行っているのが 1 回のキャンプのみで, しか 
も回答者数が 9 名と少ないことは, この研究結果 を一般化するには限界があると考えられる。

さらに，子育てに関する発見や気づきと，家族 の今後の日常生活（生きかた）に活かしていきた いことがらについて, 本研究で整理したカテゴ リーの中には, このキャンプに参加するまでの子 育ての過程で生まれた問題意識を基盤として成立 しているものがあると考えられる。そこで，この キャンプ参加前から母親が抱いている子育てに関 する問題意識と, キャンプで得た発見や気づきな どについての因果関係を今後の研究で明らかにし たい.

\section{文献}

NPO 法人子育て学協会 (2014) 幼児期の子育てに関す る悩み調查, http://kosodategaku. jp/wpcontent/uploads/2016/07/enquete.pdf（参照日： 2018 年 2 月 17 日)

上野恵子, 穴田和子, 浅生慶子, 内藤 圭, 竹中真輝 （2010）文献の動向から見た育児不安の時代的変 遷, 西南女学院大学紀要, 14, 185-195

三菱 UFJリサーチ\&コンサルティング（2014）子育 て支援策等に関する調查 2014 報告書概要, http://www.murc.jp/publicity/press_release/ press_141208.pdf（参照日：2018 年 2 月 17 日）

日本労働組合総連合会 (2013) 子ども・子育てに関す る調查, http://www.jtuc-rengo.or.jp/news/ chousa/data/20130621.pdf（参照日：2018 年 2 月 17 日)

三鈷泰代（2008）幼児期の子どもをもつ親の養育スキ ルに関する研究一親の養育スキルと子どもの行 動傾向との関連一, 発達研究, 22, 181-190

三鈷泰代 (2009) 幼览期の子どもをもつ親の養育スキ ルに関する研究一親の養育スキルと子どもの行 動傾向との関連一, 発達研究, 23, 57-72

朴 信永, 杉村伸一郎（2009）幼児を育てている親の 子育てに関する省察の 3 層モデルの検討, 発達心 理学研究, 20(2), 99-111

山下芙実子, 石暁 玲, 桂田恵美子 (2010) 大学生の 親子関係・自尊感情・生き方志向と子ども時代の 両親の養育態度との関係一過保護という養育態 度の検討一, 臨床教育心理学研究, 36, 21-26

村山 陽（2009）高齢者との交流が子どもに及ぼす影 響, 社会心理学研究, 25 (1), 1-10

中井孝章 (2007) 子どもの自己承認欲求と親からの期
待と承認の関連性一ポストヒューマニズムの立 場からの子ども研究一, 生活科学研究誌, $6,113-$ 137

佐々木尚之（2010）日本人の子育て観一JGSS-2008 デー夕に見る社会の育児能力に対する評価一, 日 本版総合的社会調查共同研究拠点研究論文集, $10,35-47$

中山智哉, 渡邊 望, 春高裕美, 木山徹哉 (2014) 母 親の育児感情に影響を及ぼす要因の探索的検 討一母親の育児方法・育児への省察抢よび保育相 談支援との関連一, 九州女子大学紀要, 50 (2), $15-29$

(受付 : 2018 年 7 月 24 日, 受理 : 2018 年 12 月 25 日)

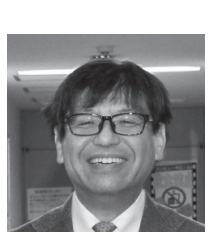

菊田 文夫（きくた ふみお）

現職 : 聖路加国際大学大学院看護学研究 科基盤領域（健康教育）准教授

東京大学大学院教育学研究科修士課程 (健康教育学) - 神戸 大学大学院総合人間科学研究科後期課程 (人間形成科学). 博士 (学術).

大妻女子大学人間生活科学研究所助手を経て, 現職. 専門 は, 健康教育学.

人間として生きる「生きかたの教育」に関する研究や教育, 実践活動に取り組んでいます。特に，さまざまな価值観を 有する大人みんなで子どもたちを見まもり，育てるコミュ ニティづくりが急務であると考え，豊かな自然の恵みを活 かした「森のようちえん」の実践的研究を進めています. もともと趣味のひとつだったアウトドアの思想を，いまの 仕事に活かせることが至上の喜びです．

主な著書・論文 :「みらいへの教科書」(単著, 学研教育み らい, 2015),「幼児の運動介入プログラムのあり方をめぐっ て〜けがを恐れず, たくましく育つために〜」(共著, 子ど もと発育発達，16（2）121-125，2018），「自然体験活動を 通して幼児の発達を支援する「森のようちえん」指導者の 資質について」(単著, いのちの教育, 3（1）7-15，2018), 「小学生の自尊感情を育むいのちの授業」(共著，いのちの 教育, 1（1）2-9，2016）ほか. 